\title{
Indigenous Knowledge Practice by Food Crops Farmers for Soil Management in Ondo State, Nigeria
}

\author{
Okunlola $\mathrm{JO}^{1 *}$ and Olayinka $\mathrm{VY}^{2}$ \\ ${ }^{1}$ Department of Agric. Economics \& Extension, Federal University of Technology, Akure, Ondo State, Nigeria \\ ${ }^{2}$ Department of Agricultural Science, TESCOM Akure, Ondo State, Nigeria
}

Article History
Received: 24.10 .2020
Accepted: 08.11 .2020
Published: 21.12 .2020
Journal homepage:
http://www.easpublisher.com
Quick Response Code

Abstract: One of the factors affecting food production in Nigeria is the problem of Soil fertility which determines the crop output by the farmers. The farmers' concept of soil fertility is closely linked to land productivity. However, the need for maximum crop production depends on effective soil classification and management practices. It is significant to state that the local farmers have developed local methods for soil classification, soil fertility techniques and management of soil in their locality. It is in consideration of the above that the study examined indigenous soil classification techniques, determined indigenous methods of soil management and examined indigenous soil fertility techniques being used by the farmers. The study adopted the use of multi-stage random sampling techniques to select One hundred forty-five [145] farmers from Ondo State. Both qualitative and quantitative methods were used to obtain data for the study. The result of the study revealed that about 32 percent of the farmers had no formal education while majority (37.2 percent) were between 51-60 years practicing mixed cropping (89\%) and mixed farming $(9.6 \%)$. In the study the farmers also stated that the presence of Echinus Hispidus, Tridax specie, Eleusine indica on the farm land indicates that the soil is not fertile, while the presence of Eupatorium odoratum, talinum triangulare, Bernono spp and kalancheo spp are indications of fertile soil. The farmers also indicated the various local methods of identifying plants that is used for organic manure. Such methods include the use of taste, waxy nature of plant and leaf strength. In soil classification, it was also found out that soil colour and texture were the two basic determining factors used by farmers for classifying soil. The result of multiple regression analysis shows that $82.4 \%$ of variation in use of indigenous knowledge to classify and improve soil fertility was explained by level of education, contact with extension agents and family practices. From the study integration of local method of soil classification and maintenance with modern techniques in a complimentary way will enhance soil utilization by the farmers for improved crop production and food security in Africa.

Keywords: Soil fertility, farmers, kalancheo spp, Tridax specie.

Copyright ( $\odot 2020$ The Author(s): This is an open-access article distributed under the terms of the Creative Commons Attribution 4.0 International License (CC BY-NC 4.0) which permits unrestricted use, distribution, and reproduction in any medium for non-commercial use provided the original author and source are credited.

\section{INTRODUCTION}

In most developing countries the worsening food situation and efforts to increase food production with unsuccessful programmes have been attributed to assumed superiority given to outside knowledge technology over internal ones by the planners [1]. The level of agricultural production in developing countries like Nigeria is not satisfactory because appropriate technologies are not yet in place, as technologies are transferred from abroad or technologies developed without the input of the farmers, the consequence is that the technologies are ineffective in solving the problems of food production and the country have to result to food importation. In some cases the poor farmers cannot afford the new technologies and the cost of input required to back up the innovation. According to Formethe [2], agricultural education and the research we carry out today were initiated by our fore-parents and passed through generations. It should also be realized that all the crops currently grown and livestock reared were bred and developed by farmers. They are all accumulation and shared knowledge from our fore fathers. There is therefore, the need to critically consider the local knowledge of the people as an input for planning, execution and evaluation of agricultural development projects towards food security in Africa. This will be a sustainable way of solving food deficit situation in Nigeria and other parts of Africa. 
Indigenous knowledge system (IKS) is a systematic body of knowledge acquired by local people through the accumulation of experience and informal experiment in an effort to cope with their agro ecological and socio economic environment [5]. IKS is location specific and dependent on social cultural universe, ethnicity, age, gender and economic status of the people as well as interactions between and within communities. It is also to be noted that it forms part of the basis for decision by the people for their production activities.

The issue of soil fertility is germane to Nigerian agriculture as it is one of the factors affecting farmers' level of production because of farmers' inability to procure inorganic fertilizers due to cost of the product, inappropriate use of inorganic fertilizer and poor soil management principles. Peter [3] stated that the greater the understanding of soil using indigenous and modern knowledge the greater is the chances of using the soil wisely. This involves having sufficient knowledge of each type of the soil and the various classes of soils that can be developed for agriculture, grazing, forestry, fishing and other purposes. Okunlola [4] asserted that indigenous method provide the template and required information for the soil scientist to come up with acceptable and sustainable innovation in soil management. It is therefore important to have the understanding of indigenous practices of local people for food production over the years.

The main objective of the study is to examine Indigenous Knowledge Practice by Food Crops Farmers for Soil Classification and Management in Ondo State. The specific objectives are to:

- Ascertain the socio-economic characteristics of the respondents

- Examine indigenous methods for soil classification by the farmers

- Determine farmers' use of indigenous method for soil fertility and organic material identification.

- Examine local method use by farmers to generate organic fertilizers.

\section{Hypotheses of the study}

$\mathrm{Ho}_{1}$ : There is no significant association between farmers' socio-economic characteristics and the use of indigenous knowledge.
$\mathrm{Ho}_{2}$ : There is no significant relationship between selected socio-economic variable and indigenous classification of soil for soil fertility

\section{Methodology}

The study was conducted in three local government areas of Ondo State, South West, and Nigeria. A multi -stage sampling technique was used for the study. Three local government areas (LGAs) specifically, Akure South, Akure North and Owo Local Government Area (LGA) were randomly selected from sixteen Local governments in the state. Five [5] villages from each LGAs were randomly selected making a total of fifteen [15] villages used for the study. The second stage involved dividing each village into three wards making a total forty five [45] wards for the three LGAs out of which two wards were selected making thirty wards (30) and five farmers were randomly selected and interviewed from each of the ward. Total sample sizes of 150 farmers were selected but, data from 145 food crops farmers was eventually used for analysis after data cleaning. A pre-tested and validated structured questionnaire with Focus group Discussion (FGD) was used for the study. Descriptive statistics, inferential statistics such as chi-square and regression were used to analyze the data.

\section{RESUlTS AND DisCUSSION}

The result revealed that 81.4 percent of the respondents are male while majority of the respondents (37.2 percent) were between $30-40$ years and the mean age was 45.5 years as shown in Table 1. The implication is that most of the respondents are experienced and have knowledge of local practices in soil management. The study further shows that $31.7 \%$ of the respondents had no formal education, $26.2 \%$ and $15.9 \%$ attend primary school and adult literacy school respectively while eighty percent were Christians, $15.2 \%$ were Muslims while $4.8 \%$ were traditional worshippers. Most of the farmers (78.6\%) were small scale farmers cultivating between 1-5 acres while 20 percent cultivated between 6-10acres. The implication is that most of the farmers were small scale farmers. From table 1, majority of the farmers( 89 percent) were into mixed cropping system of food production, cultivating maize, cassava and yam. 
Table-1: Socio- Economic Characteristics

\begin{tabular}{|c|c|c|}
\hline Variable & Frequency & Percentage \\
\hline \multicolumn{3}{|l|}{ Sex } \\
\hline Male & 118 & 81.4 \\
\hline Female & 27 & 18.6 \\
\hline \multicolumn{3}{|l|}{ Age } \\
\hline Below 30 Years & 6 & 4.1 \\
\hline $30-40$ & 54 & 37.2 \\
\hline $41-50$ & 27 & 18.6 \\
\hline $51-60$ & 39 & 26.9 \\
\hline Above 60 & 19 & 13.1 Mean $=45.5$ \\
\hline \multicolumn{3}{|l|}{ Educational Level } \\
\hline No formal Education & 46 & 31.7 \\
\hline Adult literacy School & 23 & 15.9 \\
\hline Primary School & 38 & 26.2 \\
\hline Secondary School & 20 & 13.8 \\
\hline Diploma certificate & 9 & 6.2 \\
\hline University Degree & 9 & 6.2 \\
\hline \multicolumn{3}{|l|}{ Primary Occupation } \\
\hline Farming & 114 & 78.6 \\
\hline Bricklaying & 16 & 11.1 \\
\hline Carpentry & 7 & 4.8 \\
\hline Processor & 8 & 5.5 \\
\hline \multicolumn{3}{|l|}{ Religion } \\
\hline Christianity & 116 & 80.0 \\
\hline Muslim & 22 & 15.2 \\
\hline Traditional religion & 7 & 4.8 \\
\hline \multicolumn{3}{|c|}{ Membership of Social Group } \\
\hline Yes & 56 & 38.6 \\
\hline No & 89 & 61.4 \\
\hline \multicolumn{3}{|l|}{ Farm Size(Acres) } \\
\hline $1-5$ & 96 & 66.2 \\
\hline $6-10$ & 29 & 20.0 \\
\hline $11-15$ & 11 & 7.6 \\
\hline $16-20$ & 7 & 4.8 \\
\hline Above 20 & 2 & 1.4 Mean $=13$ \\
\hline \multicolumn{3}{|c|}{ Farm Practice By Respondents } \\
\hline Mixed Cropping & 129 & 89.0 \\
\hline Mono cropping & 14 & 9.6 \\
\hline Mixed Farming & 2 & 1.4 \\
\hline
\end{tabular}

Use of Indigenous Knowledge System for soil Classification: Sixty nine percent of the respondents use Indigenous Knowledge method to classify and maintain soil on their farms as shown in table 2. The method of soil classification includes the use of texture $(40.2$ percent), colour (31.4 percent) and structure of the soil (28.3percent). Most of those who use Indigenous Knowledge for the soil classification, during Focus Group Discussion (FGD) claimed that, it has been their practice for over thirty years and that it has helped them improved their level of production.

Table-2: Indigenous method for classifying soil

\begin{tabular}{|l|l|l|}
\hline Use of IKS for soil classification & Frequency & Percentage \\
\hline Yes & 102 & 70.3 \\
\hline No & 43 & 29.7 \\
\hline Total & 145 & 100.0 \\
\hline IKS Method used & Frequency & Percentage \\
\hline Texture & 41 & 40.2 \\
\hline Colour & 32 & 31.4 \\
\hline Structure & 29 & 28.4 \\
\hline Total & 102 & 100.0 \\
\hline
\end{tabular}




\section{Local method of Classifying Soils}

The respondents locally classified soils into five local categories as shown in table 3. The soil groups are based on colour, organic matter content perceived to be present, the texture as tested locally when squeezed in their palms and felt in their hands, compaction when mixed with water and rolled with their hands, moisture retention, degree of erosion observed with the soil topography, range of crops that thrived in the soil over some time and how well drained the soil is, as indicated in table 3 below.

\begin{tabular}{|l|l|l|l|l|l|}
\hline Tharacteristics & Loamy soil & $\begin{array}{l}\text { Sandy Clay } \\
\text { Soil }\end{array}$ & Sandy soil & Clay Soil & $\begin{array}{l}\text { Wet Clay Loamy } \\
\text { Soil }\end{array}$ \\
\hline Local Name & Iledu/Aladun & Eguru & Iyanrin & $\begin{array}{l}\text { Ile amo/Odo/Ile } \\
\text { pupa }\end{array}$ & $\begin{array}{l}\text { Akuro/Bole } \\
\text { Aladun }\end{array}$ \\
\hline Colour & Black & Red & White & Red\& Brown & Brown \\
\hline $\begin{array}{l}\text { Organic Matter } \\
\text { Content }\end{array}$ & Relatively High & moderate & Low & Fairly low & High \\
\hline Texture & Heavy & Powdery & Coarse & Light\& Powdery & Gritty \\
\hline Compaction & & & & & Moderate \\
\hline Moisture Retention & Moderate & High & Low & High & Average \\
\hline Degree of Erosion & Slight & Moderate & High & Moderate & $\begin{array}{l}\text { Choice of crop is } \\
\text { limited }\end{array}$ \\
\hline Range of Crops & $\begin{array}{l}\text { Support wide range } \\
\text { of crops }\end{array}$ & $\begin{array}{l}\text { Supports few } \\
\text { crops }\end{array}$ & $\begin{array}{l}\text { Supports few } \\
\text { crops }\end{array}$ & $\begin{array}{l}\text { Support few } \\
\text { crops }\end{array}$ \\
\hline Drainage & Well drained & Poorly drained & Well-drained & Poor drained & Well drained \\
\hline
\end{tabular}

Farmers' Perception of Soil Fertility and Indigenous plants/ methods used for soil fertility identification by Respondents

From the Focus group Discussion (FGD) conducted with farmers in the area of study, it was observed that the farmers and scientist understand soil fertility in different ways. It was noted that the scientist mostly take account of the soil nutrient status(macro and micro nutrients) to considers fertile land as the soil that is capable of producing consistently high yields in a wide range of crops. However, from the farmers' perspective soil fertility is considered from the presence of some known plants on the soil. The presence of such plants gives initial indication or provides the preliminary information on the fertility of the soil and the types of crops to plant on such soils. The emergence of some weeds which may not be present in the location before also indicates declining soil fertility and helps to determine the types of crops that could be grown in such location. This is discussed in details in table 4 below.

The farmers in the study area during the FGD affirmed that presence of some plants like Echinips hispidus (teteregun), Tridax spp( isepetu) and stubborn grass [Eleusine indica] shows that the soil is not fertile while according to table 4 , the presence plants like Chromolena odarata (Akintola weed), talinum triangulare (Gbure) Bernonino spp (igi Ewuro) and Kalanchaeo spp (Odundun) indicates improved soil fertility. The farmers further stated that the presence of Digitaria horizontalis(Eran), Combretum platyperum (Okan), Mallotus oppositifolius(Pepe) are indications of poor soil fertility. Seventy eight percent of the respondents also claimed that they use waxy leaves of plants, taste and woody nature of plants to identify fertile soils as indicated in the table below:

Table-4: Indigenous plants/ methods used for soil fertility identification

\begin{tabular}{|l|l|l|l|}
\hline $\begin{array}{l}\text { Plants that indicate unfertile } \\
\text { soils }\end{array}$ & $\begin{array}{l}\text { Plants that indicate } \\
\text { fertile soil }\end{array}$ & $\begin{array}{l}\text { Vegetation that indicate } \\
\text { poor soil fertility }\end{array}$ & $\begin{array}{l}\text { Other method of Soil } \\
\text { fertility identification }\end{array}$ \\
\hline $\begin{array}{l}\text { i.Echinips hispidus(Teteregun } \\
(* 80 \%)\end{array}$ & $\begin{array}{l}\text { i.Chromolaena } \\
\text { Odorantum (Akintola) } \\
(* 81 \%)\end{array}$ & $\begin{array}{l}\text { i.Digitaria } \\
\text { horizontalis(Eran) } \\
(* 77 \%)\end{array}$ & Taste $(* 78)$ \\
\hline $\begin{array}{l}\text { ii. Tridax Spp(Isepetu) }(* 81 \%) \\
\text { ii.Talinum Triangulare } \\
(\text { Gbure) }(* 74 \%)\end{array}$ & $\begin{array}{l}\text { ii.Combretum platyperum } \\
(\text { Okan) }(* 62 \%)\end{array}$ & $\begin{array}{l}\text { Woody nature of } \\
\text { plants }(* 72 \%)\end{array}$ \\
\hline $\begin{array}{l}\text { iii.Eleusine Indica (Stubborn } \\
(* 81 \%)\end{array}$ & $\begin{array}{l}\text { ii.Bernonino Spp (Igi } \\
\text { Ewuro) }(* 44 \%)\end{array}$ & $\begin{array}{l}\text { iii.Mallotus } \\
\text { oppositifolius(Pepe) } \\
(* 52 \%)\end{array}$ & $\begin{array}{l}\text { Waxy leaves } \\
(* 85)\end{array}$ \\
\hline & $\begin{array}{l}\text { iv.Kalancheo } \\
\text { Spp(Odundun) }(* 86 \%)\end{array}$ & & \\
\hline
\end{tabular}

*Mutiple response by respondents 


\section{Farmers' method of organic material identification} and organic fertilizer production

From the study, the respondents have methods of identifying plant organic material. Majority of the respondents $(77 \%)$ stated that the colour of the leaves of a plant determines the suitability of the plant. The farmers believed that plants with green leaves will make good organic fertilizer while yellow plants will be a poor source of organic fertilizer. Another factor is also the strength of the leaves; $63 \%$ of the respondents asserted that if a leaf can be easily torn with fingers, such leaf will be a good source of organic fertilizer but if it is hard it means it has low element to add to the soil. The International Institute of Rural Construction [1] also confirmed the farmers' assertion that it is due to lignin in the plant tissue. The study also found that the farmers' use taste to determine the suitability of plants as organic fertilizer. About $72 \%$ of the respondents stated that if the plant is astringent when tasted, it will not make good fertilizer.

Apart from the above, the study found that the farmers have local method for generating fertilizers. The farmers cut into pieces and soak in water for five days plants of efirin (occimum graticsimum), Akintola (Chromolena odorata), ewuro/bitter leave (Vernonia amygdalina), Neem /Dogoyaro leaves (Azadirachta indica), the soaked plant are stirred after the initial three days. It is to be noted that the ratio of plant materials and water is 3:1. The product is removed and applied after five days as organic manure .About sixty percent of the farmers during FGD claimed that they have been using the organic material generated as their main source of fertilizer for over 25 years.

\section{Method Used In Maintaining Soil Fertility}

It was discovered that majority of the respondents, (38.6\%) used green manure as indigenous method for maintaining soil fertility as shown in table 5 . About $28.3 \%$ used crop rotation, $13.8 \%$ used mulching while $11.0 \%$ utilise compost from local materials such as green leaves with potential for fertility as identified by taste and colour. The farmers claimed that plants with green leaves have high fertility potential and also if the plant leaves tears easily and astringent when tasted they are indicators that the leaves have high fertility potential.

Table-5: local Soil Fertility practices

\begin{tabular}{|l|l|l|}
\hline $\begin{array}{l}\text { IKS Maintenance } \\
\text { Methods }\end{array}$ & Frequency & Percentage \\
\hline Green Manuring & 56 & 38.6 \\
\hline Crop Rotation & 41 & 28.3 \\
\hline Mulching/Residues & 20 & 13.8 \\
\hline Compost Making & 16 & 11.0 \\
\hline Fallowing & 12 & 8.3 \\
\hline Total & 145 & 100.0 \\
\hline
\end{tabular}

\section{Hypothesis Testing}

$\mathrm{Ho}_{1}$ : There is no association between the socio-economic characteristics of respondents and the use of Indigenous method.

The study found that gender, education and farm size do not influence the use of Indigenous method for soil management in the study area as indicated in table 6. However, religion and status had significant relationship with the use of indigenous methods. During the Focus Group Discussion it was found out that some of the farmers with high economic status and who can who can afford the cost of inorganic fertilizers and agrochemicals now sparingly use indigenous methods on their farms, they prefer to use the inorganic materials and also carry out soil tests to determine soil classification and fertility.

Table-6: Association between socio-economic characteristics of respondents and the use of Indigenous knowledge

\begin{tabular}{|l|l|l|l|l|}
\hline Variables & Calculated $^{\mathbf{X} 2}$ value & Tabulated $^{\mathbf{2}}$ value & Degree of Freedom & Decision \\
\hline Gender & 2.987 & 5.99 & 2 & NS \\
\hline Education & 11.830 & 21.03 & 12 & NS \\
\hline Age & 7.577 & 15.51 & 8 & NS \\
\hline Religion & 23.785 & 9.49 & 4 & $S^{*}$ \\
\hline Economic Status & 45.962 & 9.49 & 4 & S $^{*}$ \\
\hline Farm Size & 8.784 & 9.49 & 4 & NS \\
\hline
\end{tabular}

Significant at 0.05

$\mathrm{Ho}_{2}$ : There is no significant relationship between selected socio-economic variables and indigenous classification of soil for fertility.

The study shows that out of five [5] independent variables used to regress the use of indigenous knowledge for classifying and improving soil fertility. Only three [3] of the independent variables were able to predict up to $82.4 \%$ of the total variation, the independent variables are level of education, extension contact and farming experiences. Level of
Education predicted the use of indigenous knowledge and it is significant at 0.05 . It implies that the level of education, the lower the use of indigenous knowledge in classifying and improving soil fertility, this support Okunlola [4] assertion that the higher the educational level, the lesser the use of indigenous knowledge. Farming experience is another contributor. The more experienced the farmers are, the higher the tendency to continue to use indigenous knowledge to classify and improve soil fertility. 
Table-7: Empirical Result of the Multiple Stepwise Regression Analysis

\begin{tabular}{|l|l|l|l|l|l|}
\hline Variable & Regression Coefficient & Standard Error & Wald & Sig. & Decision \\
\hline Farm size & 3.304 & 2.182 & 2.294 & 0.130 & NS \\
\hline Age & 1.419 & 1.386 & 1.049 & 0.306 & NS \\
\hline Education & 7.269 & 1.971 & 13.604 & 0.000 & $\mathrm{~S}^{*}$ \\
\hline Extension Contact & 5.102 & 2.047 & 6.215 & 0.013 & $\mathrm{~S}^{*}$ \\
\hline Farming Experience & 8.266 & 2.554 & 10.478 & 0.001 & $\mathrm{~S}^{*}$ \\
\hline Constant & 8.054 & 1.723 & 21.848 & 0.000 & \\
\hline
\end{tabular}

Significant at 0.05

\section{CONCLUSION}

The study has shown that the farmers use texture, colour and structure to classify soils while the presence of some local plants were also used to identify fertile and unfertile soils, Colour and taste of plants were also used to identify organic materials and suitability of plants for soil fertility. Local methods such as the use of green manure, mulching among others were used to maintain soil fertility while local plants such as efirin (occimum graticsimum), Akintola (Chromolena odorata), ewuro/bitter leave (Vernonia amygdalina), Neem/Dogoyaro leaves (Azadirachta indica) were processed into organic fertilizers. The study also concluded that religion and status had significant relationship with the use of indigenous methods.

\section{REFERENCES}

1. Atteh, D.O. (1990). "Participatory Research and Development. The Route to sustaining Agriculture and Rural Development in Nigeria." Paper presented at the Workshop on Farmers Participatory Research Experience and Future Actions Workshop. Abeokuta, 4-15.

2. Formethe, A. (2014). Creating wealth and prosperity through Business- oriented agriculture and natural resources education and research. $4^{\text {th }}$ ANAFE Symposium Yaounde, 10.

3. Peter, M. (1979). West African Soils. Printed by Oxford University Press, 254-256.

4. Okunlola, J.O. (1997). "Analysis of indigenous Approach to the control of Rice Oests and Diseases in Ekiti and Niger State, Nigeria" Unpublished Ph. D Thesis, University of Ibadan, 15- 23.

5. Warren, D.M., \& Rajasekaran, B. (1993). Putting Local Knowledge to Good Use. Published in International Agricultural Development. July/August, 34-38. 